\title{
Perspektif Hukum Ekonomi Syariah: Kebijakan Pemerintah Dalam Mengatasi Perekonomian Masa Pandemic Covid 19
}

\author{
Eni Kusrini \\ IAIN Kudus \\ enikusrini50@yahoo.com
}

\begin{abstract}
Pandemic covid 19 is increasingly significant in Indonesia, so the economy is unstable. This is caused by paralysis of activities in all dimensions of life so that the economy is completely paralyzed. Government policy is needed to be able to survive in the covid pandemic 19, so as to suppress the rate of inflation and the community is able to survive in the midst of the economic crush in accordance with Islamic economic law studies. Islamic scientific studies in the realm of sharia macroeconomics need to be carried out in order to be able to suppress and even overcome the problems that occur in the State of Indonesia today. How the government efforts are able to work together with all the various communities able that this outbreak is able to be overcome and not prolonged.
\end{abstract}

Key words: covid 19, macroeconomics, government policy

\begin{abstract}
Abstrak
Pandemic covid 19 semakin hari sangat signifikan kasusnya di Indonesia, sehingga perekonomian menjadi tidak stabil. Hal ini disebabkab oleh lumpuhnya aktifitas di segala dimensi kehidupan sehingga ekonomi benar-benar lumpuh. Kebijakan pemerintah sangat diperlukan untuk dapat bertahan dalam pandemic covid 19 ini, agar dapat menekan laju inflasi dan masyarakat mampu bertahan di tengah himpitan ekonomi tersebut sesuai dengan kajian hukum ekonomi syariah. Kajian keilmuan Islam dalam ranah ekonomi makro syariah perlu dilaksanakan agar mampu menekan bahkan menanggulangi permasalahan yang terjadi di Negara Indonesia saat ini. Bagimana upaya pemerintah mampu bersinergi dengan seluruh kaalangan berbagai masyarakat agar wabah ini mampu ditanggulangi dan tidak berkepanjangan.
\end{abstract}

Kata kunci : covid 19, ekonomi makro, kebijakan pemerintah

\section{PENDAHULUAN}

Kehidupan ekonomi merupakan suatu standar kehidupan individu dan kolektif suatu Negara. Keunggulan Negara sering diukur dari keberhasilan kemajuan ekonominya, sehingga menjadikan sebuah kehidupan menjadi matererialistik dan saling berkompetensi dalam mencapai keberhasilan. Kekuatan besar yang mengendalikan kehidupan dunia yaitu ekonomi dan agama (Prof. Dr. H. Juhaya S. Pradja, 2015: 39).

Sebuah keyakinan dan kebenaran yang wajib kita teladani bahwa Rosululah SAW merupakan aktivis ekonomi Islam yang mengajarkan tradisi perdagangan, pengelolaan harta kekayaan Negara dan hak-hak rakyat. Kita memahami bahwa fungsi dari doktrin ekonomi yaitu 
Perspektif Hukum Ekonomi Syariah: Kebijakan Pemerintah dalam Mengatasi Perekonomian Masa Pandemi Covid 19

memecahkan masalah dalam kehidupan yang berhubungan dengan konsep ideologi dan cita-cita keadilan.

Pada zaman sekarang ini, terlebih ditengah wabah pandemic covid 19, perekonomian menjadi suatu tantangan yang sangat fantastis keberadaannya secara global, khususnya di Negara Indonesia. Wabah Covid 19 dinyatakan oleh WHO (World Health Organization) sebagai darurat kesehatan masyarakat. Virus corona adalah virus yang menyebabkan flu biasa hingga penyakit yang lebih parah seperti sindrom pernafasan dan sindrom pernaafasan akut parah. Dugaan sementara virus corona ditularkan dari hewan ke hewan. Kemudian diketahui virus tersebut juga mampu menularkan dari manusia ke manusia (Mukharom, Havis Aravik, 2020: 240).

Wabah Covid 19 tidak hanya berdampak pada segi kesehatan saja melainkan sudah merambah pada multi dimensi kehidupan mulai dari hukum, sosial, politik, budaya, religius, termasuk perekonomian Negara. Tatanan perekonomian menjadi tidak stabil, munculnya inflasi yang ditandai dengan kenaikan harga barang, tingkat suku bunga, dan ketidakmerataan distribusi pendapatan. Kajian dengan tema Kebijakan Pemerintah Dalam Mengatasi Perekonomian Pada Masa Covid 19 ini dilatarbelakangi oleh adanya wabah Covid 19 yang semakin meningkat kasusnya di Negara Indonesia sehingga menjadikan perekonomian menjadi krisis dan tidak stabil yang berdampak pada Negara dan seluruh masyarakat Indonesia. Sehingga pada kajian ini akan mengkaji akibat dari pandemic covid 19 bagi perekonomian di Negara Indonesia, memberikan solusi perekonomian melalui worldview Islam dan kebijakan ekonomi makro dalam perspektif Hukum Ekonomi Syariah.

\section{KAJIAN LITERATUR}

\section{Perspektif Hukum Ekonomi Syariah}

Dalam memahami eksistensi hukum Islam dalam sistem nasional dalam perspektif pergulatal politik hukum, dapat ditelaah dari pelbagai teori yang dijadikan sebagai demarkasi sejarah hukum Islam di Indonesia. Untuk menuju teori eksistensi hukum Islam dalam tata hukum lndonesia yang merupakan cerminan kemurnian dan politik kepentingan mendangkalkan ajaran Islam, dapat dipahami melalui beberapa teori sebagai berikut: pertama, teori ajaran Islam tentang penataan hukum, yang mendasarkan berlakunya hukum Islam berdasarkan Al-Qur'an dan Sunah.

Penerapan Ekonomi Syariah dalam Perspektil Politik Hukum; Kedua, teori penerimaan otoritas hukum yang menegaskan bahwa setiap seorang dan siapapun yang telah menyatakan dirinya sebagai seorang Muslim, dengan mengucapkan dua kalimat syahadat, ia terikat untuk patuh dan taat kepada hukum dan ajaran Islam; ketiga, teori receptio in complexu adalah teori yang menanamkan bagi setiap penduduk berlaku 
hukum agamanya masing-masing, keempat; teori receptie menegaskan hukum Islam tidak otomatis berlaku bagi orang Islam. Jadi hukum Islam berlaku bagi orang Islam, kalau ia sudah diterima (diresepsi) oleh dan telah menjadi hukum adat. Jadi yang berlaku bukan hukum Islam, tetapi hukum adat; kelima, teori receptie exit sebagai bentuk perlawanan terhadap theorie receptie, teori ini mempakan bagian dari keberhasilan usaha tokoh-tokoh kebangsaan yang selalu memperjuangkan berlakunya hukum Islam bagi orang Islam; keenam, teori receptio a contraio yang menyatakan bahwa hukum yang berlaku bagi rakyat adalah hukum agamanya. Dengan demikian hukum adat hanya akan berlaku jika tidak bertentangan dengan hukum Islam; dan ketfiuh, teori eksistensi yang menerangkan tentang adanya hukum Islam dalam Hukum Nasional Indonesia (Pelu, AS, Pelmi, Ibnu, 2008:96).

\section{Pandemic Covid 19}

Pada tanggal 11 Maret 2020 WHO (World Health Organization) mengemukakan bahwa covid 19 merupakan wabah secara global. Covid 19 merupakan wabah yang berbahaya dan menular. Pada penanganan covid 19 banyak Negara melakukan lockdown dan mitigasi kegiatan dengan tujuan menekan laju pertambahan pasien covid 19. Beberapa tindakan yang dilakukan yaitu melakukan isolasi, menyediakan tempat rawat inap, dan pelacakan kontak dengan penderita covid 19. Sosialisasi upaya pencegahan dalam masyarakat juga telah disosialisasikan seperti mencuci tangan, social distancing, isolasi, dan pelarangan pertemuan masal dalam berbagai momentum (Comment, Vol. 395, March 28, 2020:1016).

Corona Virus Disease (Covid 19) merupakan jenis virus baru yang menular pada manusia dan menyerang sistem pernafasan dan dapat berujung pada kematian. Tanda-tanda secara umum seseorang terinfeksi virus ini adalah demam tinggi (di atas 38 derajat celcius), batuk dan sesak nafas. Awal mula virus ini berasal dari pasar hewan liar di kota Wuhan. Virus tersebut menyebar secara cepat ke berbagai belahan dunia termasuk Indonesia. Berdasarkan informasi dari Kementerian Kesehatan Republik Indonesia terkait upaya pencegahan untuk mengurangi risiko terinfeksi virus Covid-19 adalah sebagai berikut (Kemkes RI, 2020):

1. Mengonsumsi makanan yang dimasak sempurna, bergizi baik, dan tidak mengonsumsi makanan yang berpotensi menularkan.

2. Melakukan aktivitas fisik seperti berolahraga dan diimbangi istirahat yang cukup.

3. Melakukan perilaku hidup bersih dan sehat (PHBS) seperti mencuci tangan dengan sabun dan air mengalir setelah beraktivitas.

4. Menggunakan masker apabila merasa tubuh kurang sehat dengan gejala batuk dan bersin-bersin.

5. Apabila kondisi tubuh melemah, terutama dengan gejala demam dan sesak napas, segera periksakan diri ke fasilitas kesehatan. 
Perspektif Hukum Ekonomi Syariah: Kebijakan Pemerintah dalam Mengatasi Perekonomian Masa Pandemi Covid 19

\section{METODE PENELITIAN}

\section{Jenis dan Pendekatan Penelitian}

Jenis penelitian ini adalah penelitian lapangan. Sedangkan pendekatan yang digunakan pada penelitian ini adalah pendekatan kualitatif. Penelitian lapangan merupakan suatu jenis penelitian yang mempunyai tujuan untuk mempelajari tentang latar belakang keadaan pada saat ini (Nurlina T.Muhyiddin, dkk, 2017:13). Sedangkan pendekatan kualitatif yaitu metode penelitian yang menekankan aspek pemahaman secara mendalam terhadap suatu permasalahan daripada melihat permasalahan tersebut sebagai sumber untuk penelitian.

\section{Setting dan Subyek penelitian}

Setting penelitian ini tentang lokasi dan waktu penelitian. Lokasi penelitian ditentukan secara sengaja didasarkan pada kriteria atau pertimbangan tertentu (Sugiyono, 2004:392). Dalam penelitian ini, penelitian mengarah pada keadaan ekonomi Negara Indonesia akibat pandemic covid 19. Subyek penelitian bersumber dari penelitian dan wawancara yang dapat memberikan beberapa informasi tentang situasi dan kondisi penelitian.

\section{Sumber Data} berikut :

Sumber data yang digunakan pada penelitian ini adalah sebagai

1. Data Primer

Data primer adalah data yang didapatkan langsung dari subyek penelitian dengan pengambilan data secara langsung pada narasumber (Saiduddin Azwar, 2001: 91) Sumber data primer yang digunakan selama penelitian adalah hasil wawancara langsung dari narasumber.

2. Data Sekunder

Data sekunder merupakan sumber yang tidak langsung memberikan data kepada peneliti, misalnya melalui orang lain atau dokumen. Sumber dari data sekunder berasal dari sumber pendukung yang nantinya dapat memberikan beberapa informasi tambahan dalam penelitian. Data sekunder diperoleh dari bacaan, arsip, serta literatur kepustakaan yang membahas tentang manajemen bisnis ritel.

\section{Teknik Pengumpulan Data}

Pada penelitian ini, teknik pengumpulan data yang dilakukan penulis melalui beberapa tahap yaitu sebagai berikut:

3. Pengamatan (Observasi)

Observasi merupakan sebuah pengamatan dan pencatatan suatu objek dengan sistematika fenomena yang diselidiki (Sukandarrumidi, 2004: 69). Pada teknik pengumpulan data ini, peneliti harus melakukan 
pengamatan baik secara langsung maupun tidak langsung terhadap obyek penelitian. Pada penelitian ini, peneliti melakukan pengamatan dampak dari pandemic covid 19 terhadap perekonomian Indonesia.

4. Wawancara

Wawancara adalah salah satu teknik pengumpulan data dengan cara melakukan tanya jawab kepada obyek penelitian. Pelaksanaan teknik dapat dilakukan secara langsung berhadapan dengan obyek penelitian, dan juga dapat dilakukan secara tidak langsung seperti memberikan daftar pertanyaan untuk dijawab oleh obyek penelitian pada kesempatan lain. Pada wawancara ini, peneliti melakukan wawancara dengan koordinator dan konsumen Minimarket Pura Tanjung Mas Kudus.

5. Dokumentasi

Dokumentasi dapat berupa catatan pribadi, laporan kerja, notulen, catatan kasus, rekaman video, foto, dan lain-lain (Sukandarrumidi, 2004:101). Data-data pada landasan teori dapat di diperoleh dari beberapa literatur, seperti buku, internet, dan sumber referensi lainnya. Dalam hal ini, peneliti melakukan dokumentasi melalui data-data dari Koperasi Karyawan Pura Group dan foto-foto yang diberikan oleh Minimarket Pura Tanjung Mas Kudus.

\section{Pengujian Keabsahan Data}

Uji keabsahan data yang digunakan dalam penelitian ini yaitu teknik triangulasi. Patton yang mengutip buku dari Lexy J. Moleong mengatakan bahwa triangulasi dengan sumber berarti membandingkan dan mengecek balik derajat kepercayaan suatu informasi yang diperoleh melalui waktu dan alat yang berbeda dalam penelitian kualitatif (Lexy J. Moleong, 2017: 330-331).

\section{Teknik Analisis Data}

Teknik analisis data yan digunakan dalam penelitian ini bersifat deskriptif-normatif. Data-data dalam penelitian ini dikumpulkan dari berbagai sumber baik secara langsung maupun tidak langsung. Kemudian disajikan dalam bentuk tulisan. Dan langkah terakhir yaitu dilakukan analisis. Tahapan-tahapan yang dilakukan peneliti adalah sebagai berikut:

1. Mengumpulkan data. Data yang dikumpulkan pada penelitian ini berasal dari wawancara, pengamatan, serta dokumentasi.

2. Memilih data yang dapat dijadikan pedoman untuk penelitian selanjutnya.

3. Melakukan penelaahan terhadap data-data yang terkumpul. Hal ini dilakukan melalui teknik-teknik yang dapat digunakan kemudian melakukan pemeriksaan kebenaran. Jika nantinya ada kesalahan maka akan dilakukan perbaikan sehingga mempermudah proses penelitian selanjutnya. 
Perspektif Hukum Ekonomi Syariah: Kebijakan Pemerintah dalam Mengatasi Perekonomian Masa Pandemi Covid 19

4. Data-data yang telah ada akan dideskripsikan secara verbal. Setelah itu peneliti akan memberikan penjelasan dan uraian berdasarkan pemikiran yang logis. Selain itu, peneliti juga akan memberikan argumentasi sehingga dapat ditarik kesimpulan.

\section{PEMBAHASAN}

\section{Dampak Pandemic Covid 19 bagi Perekonomian di Negara Indonesia}

Virus corona memberikan dampak negatif yang sangat signifikan pada sektor perekonomian beberapa Negara di dunia seperti jatuhnya harga minyak dunia. Di Asia kita juga mengalami harga bursa saham yang jatuh. Indonesia sendiri termasuk negara yang terkena dampak dari virus corona. Direktur Pelaksana Bank Dunia Mari Elka Pangestu memperkirakan pertumbuhan ekonomi Indonesia bisa melemah di bawah $5 \%$ pada kuartal I-2020. Penurunan PDB Cina hingga satu persen poin akan mengkoreksi pertumbuhan ekonomi Indonesia sebesar 0,3 persen poin.

Pelemahan ekonomi Indonesia bisa terjadi karena Cina merupakan salah satu mitra dagang terbesar Indonesia. Cina merupakan salah satu penyumbang wisatawan terbesar Indonesia. Pada Tanggal 28 Januari 2020 Menteri Keuangan Sri Mulyani menyampaikan dampak virus Corona terhadap perekonomian Indonesia. Menurut Sri Mulyani, munculnya virus corona telah memunculkan pesimisme terhadap pertumbuhan ekonomi dunia. Melihat peran China yang begitu besar berdasarkan data BPS, impor nonmigas Indonesia dari Cina tercatat mencapai 44,578 miliar dolar AS pada 2019--terbesar dibandingkan impor dari negara-negara lain. Sementara ekspor Indonesia ke Cina tercatat sebesar 25,852 miliar dolar AS. Cina juga merupakan tujuan ekspor paling besar bagi Indonesia (Burhanudin, Iksan, Chairul, dan Abdi, Nur, Muhammad, AkMen, Volume 17 Nomor 1 Maret 2020: 97).

Melemahnya keadaan ekonomi di Indonesia, juga sangat berdampak signifikan pada pelaku ekonomi mikro. Inflasi yang terjadi mengakibatkan proses produkssi yang tidak produktif, pengangguran, tingkat harga yang tidak stabil dan sebagainya . Kesenjangan ekonomi pada masyarakat Indonesia sangat terlihat jelas. Apalagi masa lockdown saat ini yang mengakibatkan sebagian besar masyarakat kehilangan mata pencaharian dan pemerintah berupaya memberikan subsidi tanpa adanya planning pada RAPBN (Rencana Anggaran Pendapatan dan Belanja Negara) sebelumnya. Semuanya itu akan menghambat dari pertumbuhan ekonomi Negara Indonesia.

Worldview Tentang Hukum Ekonomi Syariah Masa Pandemic Covid 19

Menurut Al Mauwdudi, Worldview adalah pandangan hidup yang dimulai dari keesaan Tuhan (syahadah) yang berimplikasi pada keseluruhan kegiatan kehidupan manusia di dunia, sebab syahadah adalah 
pernyataan moral yang mendorong manusia untuk melaksanakan kehidupan secara menyeluruh (Zarasyi, Fahmy, Hamid, Jurnal Tsaqafah, 2013:20).

Menurut Naquib al Attas worldview Islam memiliki elemen dan konsep-konsep yang tak terpisahkan, yaitu 1) Konsep tentang hakikat Tuhan,. 2) Konsep tentang wahyu (Al quran), 3) Konsep tentang penciptaan, 4) Konsep tentang hakikat kejiwaan manusia, 5) Konsep tentang ilmu, 6) Konsep tentang agama, 7) Konsep tentang kebebasan, 8) Konsep tentang nilai dan kebajikan, 9) Konsep tentang kebahagiaan (Zarasyi, Fahmy, Hamid, Jurnal Tsaqafah, 2013:20).

Worldview Islam terkait pada kajian Ilmu Islam Terapan mampu memberikan solusi konkret dalam bentuk varian keterampilan, yaitu :

1. Tauhid loyalitas kepada semua regulasi terkait solusi covid 19 oleh seluruh omponsen bangsa.

2. Pemberdayaan sumber daya ketuhanan YME untuk menumbuhkan kekebalan fisik mlalui medical spiritual skill.

3. Menumbuhkan sumber daya ibadah dalam menggerakkan seluruh komponen bangsa untuk melakukan physical distancing sebagai bentuk pengabdian kepada Allah SWT

4. Menggunakan teknologi keberagamaan Indonesia sebagai basis kebijakan pemerintah dan partisipasi seluruh rakyat Indonesia. Keseluruhan solusi konkret ini juga berperan penting terhadap perekonomian yang ada di Indonesia. (Mengutip dari Prof. Dr. H. Muslim A. Kadir, M.A pada tanggal 16 April 2020)

Ketika berbicara tentang wabah pada masa Rasulullah Saw juga pernah ada Penyakit menular seperti pes dan lepra. Nabi pun melarang umatnya memasuki daerah yang terkena wabah dan janganlah meninggalkan tempat tersebut. Metode karantina juga dilakukan agar wabah tersebut tidak menjalar ke Negara-negara lainnya. Bagi yang melarikan diri diancam dengan malapetaka dan kebinasaan. Oleh karena itu Nabi Muhammad Saw menjadi suri tauladan yang senantiasa dijalankan baik urusan dunia maupun akhirat. Mulai dari urusan kecil sampai besar (Mukharom dan Aravik, Havis, 2020:242). Sebagaimana firman Allah dalam QS. Al-Qalam 68 Ayat 4:

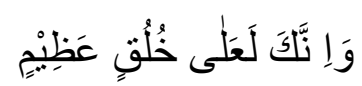

Artinya: "Dan sesungguhnya engkau benar-benar, berbudi pekerti yang luhur."

QS. Al-Ahzab 33 Ayat 21:

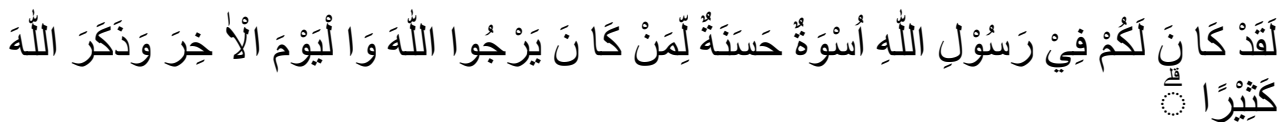


Perspektif Hukum Ekonomi Syariah: Kebijakan Pemerintah dalam Mengatasi Perekonomian Masa Pandemi Covid 19

Artinya: "Sungguh, telah ada pada (diri) Rasulullah itu suri teladan yang baik bagimu (yaitu) bagi orang yang mengharap (rahmat) Allah dan (kedatangan) hari Kiamat dan yang banyak mengingat Allah"

\section{Kebijakan Ekonomi Makro Perspektif Nasional dan Islam Pada Perekonomian Di Indonesia Di Tengah Pandemic Covid 19}

Kebijakan Gubernur DKI Jakarta berdasarkan nomor 5 tahun 2020 tentang Peniadaan Sementara Kegiatan Peribadatan dan Keagamaan Di Rumah Ibadah Dalam Rangka Mencegah Penyebaran Wabah corona virus disease (COVID-19). Pemerintah menyampaikan peniadaan kegiatan peribadatan dan kegiatan keagamaan lainnya yang mengumpulkan orang banyak yang dilaksanakan di Masjid, Gereja, Pura, Wihara, Klenteng dan tempat ibadah lainnya termasuk diantaranya ibadah shalat jumat, kebaktian, ibadah dan misa minggu, majelis taklim, perayaan hari besar dan lain-lainnya (Rezki, Anissa, dan Yunus, Rohim, Nur, SALAM Vol. 7 No. 3 (2020) : 231) .

Dalam pasal 9 Undang-Undang Nomor 6 tahun 2018 menyebutkan bahwa penyelenggaraan karantina bertujuan untuk melindungi masyarakat dari penyakit dan atau faktor resiko Kesehatan Masyarakat yang berpotensi menimbulkan Kedaruratan Kesehatan Masyarakat, mencegah dan menangkal penyakit dan/atau Faktor Risiko Kesehatan Masyarakat yang berpotensi menimbulkan Kedaruratan Kesehatan Masyarakat, meningkatkan ketahanan nasional di bidang kesehatan masyarakat, memberikan pelindungan dan kepastian hukum bagi masyarakat dan petugas kesehatan. Peraturan pemerintah ini sangat berpengaruh pada roda perekonomian baik individu maupun Negara. Oleh karena itu kebijakan yang perlu ditempuh dalam ekonomi syariah yaitu :

1. Konsep Dasar Ekonomi Makro Syariah

Permasalahan ekonomi makro saat ini terjadi hampir secara menyeluruh di Negara yang ada pada belahan dunia. Hal ini diakibatkan oleh adanya pandemic covid 19 yang muncul di Wuhan, China sekitar akhir Tahun 2019. Pandemic covid 19 menghancuran sistem tata perekonomian di setiap Negara. Sehingga perlu adanya kajian ekonomi makro melalui kebijakan-kebijakan yang dilakukan oleh pemerintah Indonesia.

Ekonomi makro merupakan studi tentang ekonomi secara keseluruhan (agregate). Ekonomi makro menjelaskan perubahan ekonomi yang mempengaruhi household, perusahaan, dan pasar. Pada intinya ekonomi makro menganalisis penentuan tindakan ekonomi yang diukur melalui pendapatan. Tujuan dan sasaran analisis ekonomi makro antara lain membahas permintaan agregate dalam menentukan tingkat kegiatan ekonomi, pentingnya kebijakan dan campur tangan pemerintah untuk 
mewujudkan keunggulaan kegiatan ekonomi yang diharapkan (Yuniarti, Sri, Vinna, 2016: 36)

Keadaan perekonomian yang sulit seperti saat ini, kehadiran ilmu ekonomi Islam bertujuan membangun mekanisme kekayaan yang adil dan kepedulian di tengah kehidupan masyarakat yang semakin kesulitan ekonomi sehingga menjadikan kesenjangan kehidupan ekonomi dalam masyarakat. Selam Islam mengajarkan kita untuk melakukan kepedulian dan tolong menolong terhadap sesama umat manusia, sebagaimana firman Allah SWT dalam Q.S At Taubah (9): 34

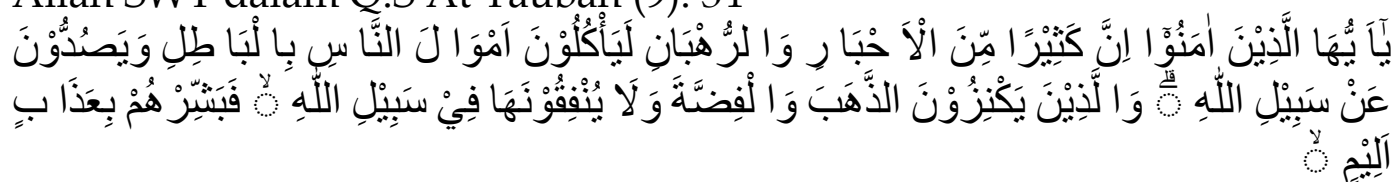

Artinya: " Hai orang-orang yang beriman, sesungguhnya sebahagian besar dari orang-orang alim Yahudi dan rahib-rahib Nasrani benarbenar memakan harta orang dengan jalan batil dan mereka menghalang-halangi (manusia) dari jalan Allah. Dan orangorang yang menyimpan emas dan perak dan tidak menafkahkannya pada jalan Allah, maka beritahukanlah kepada mereka, (bahwa mereka akan mendapat) siksa yang pedih".

Ayat di atas menjelaskan tentang larangan penimbunan harta dan pengumpulan harta secara berlebihan yang akan berakibat pada berhentinya roda perekonomian. Penimbunan merupakan perilaku yang dilarang dalam Islam dan kita senantiasa saling memberikan bantuan dan kepedulian bagi saudara kita yang membutuhkan. Kita juga harus menjaga iman dan kesabaran agar tidak ikut serta melakukan kebatilan ditengah kesulitan ekonomi saat ini.

Kekhawatiran akan Inflasi atau kenaikan harga-harga yang tinggi yang nantinya berkelanjutan akan memberikan dampak buruk pad individu dan masyarakat, para penabung, kreditor, debitor dan produsen ataupun kegiatan perekonomian secara keseluruhan. Dampak inflasi terhadap individu dan masyarakat mencakup:

a. Menurunnya tingkat kesejahteraan kepada masyarakat

Inflasi menyebabkan dayabeli masyaraat menjadi menurun, apalagi bagi yang berpendapatan tetap, kenaikan upah tidak secepat kenaikan harga-harga sehingga inflasi menurunkan upah riil setiap individu yang mempunyai pendapatan tetap.

b. Memperburuk distribusi pendapatan

Bagi masyarakat yang berpendapatan tetap akan menghadapi kemerosotan nilai riil dari pendapatannya dan pemilik kekayaan dalam bentuk uang akan mengalami penurunan juga. Akan tetapi bagi pemilik kekayaan tetap seperti tanah dapat mempertahankan atau menambah nilai riil kekayaan yang dimilikinya. (Huda, Nurul, dkk, 2008 : 180). 
Perspektif Hukum Ekonomi Syariah: Kebijakan Pemerintah dalam Mengatasi Perekonomian Masa Pandemi Covid 19

2. Bentuk-bentuk campur tangan pemerintah

a. Membuat peraturan

Tujuan pokok dari pembuatan peraturan pemerintah adalah agar kegiatan ekonomi dilaksanakan secara wajar dan tidak merugikan khalayak ramai. Contohnya peraturan tanggap bencana wabah covid 19.

b. Menjalankan kebijakan fiskal

Merupakan strategi dan langkah-langkah pemerintah dalam pengeluarannya dan dalam sistem tata cara pengumpulan pajak. Pelaksanaan kebijakan fiskal dilakukan dengan tujuan menekan dari pengeluaran pemerintah. Kebijakan fiscal dibedakan dalam dua keadaan yaitu pertama keadaan dimana inflasi berlaku tanpa control pemerintah, kedua inflasi yang diatasi dengan kebijakan fiskal.

c. Kebijakan moneter

Merupakan tindakan pemerintah dalam mempengaruhi situasi keuangan dalam perekonomian, yaitu mempengaruhi suku bunga, operasi bank, dan mengatur jumlah uang yang beredar. Kebijakan mmoneter berisi peraturan dan ketentuan yang dikeluarkan oleh otoritas moneter (bank sentral) untuk mengendalikan jumlah uang beredar. Ketika pertumbuhan ekonomi menjadi cepat dan inflasi menjadi masalah yang semakin besar, maka bank sentral dapat melakukan operasi pasar terbuka (open market operations), menarik uang dari system perbankan, menaikkan persyaratan cadangan minimum, atau menaikkan tingkat diskonto (Huda, Nurul, dkk, 2008: 183). Kedua kebijakan tersebut dalam menghadapi masalah inflasi dan pengangguran, kebijakan ini merupakan tindakan untuk mengatasi kenaikan harga dan kekurangan pekerjaan (Yuniarti, Sri, Vinna, $2016: 274$ ).

3. Kebijakan Pemerintah Republik Indonesia di tengah Pandemic covid 19

Kebijakan serta stimulus ekonomi yang dilakukan oleh Pemerintah diantaranya pemerintah menggratiskan beban listrik bagi konsumen PLN dengan daya 450 VA selama 3 bulan ke depan, yakni untuk biaya April, Mei, dan Juni 2020. Pembatasan social berskala besar untuk mencegah penularan covid 19. Larangan mudik ke daerah asal, keringanan kredit, seperti pengemudi ojek online, nelayan, dan sopir taksi, yang dipastikan akan mendapat kelonggaran kredit kendaraan bermotor selama 1 tahun, terhitung mulai 1 April 2020 ini. Keringanan juga diberlakukan bagi pengusaha sektor kecil dan menengah yang melakukan kredit di bawah Rp 10 miliar. Pemerintah Pusat menggelontorkan anggaran sebanyak Rp 405,1 triliun melalui (APBN) tahun 2020 sebagai tindakan penanganan covid 19. (https://www.kompas.com/tren/read/2020/04/01/160000765/5, diakses pada tanggal 17 April 2020). 
Pemerintah juga memberikan bantuan kepada pelaku UMKM yang berdampak adanya covid 19. Pemerintah menetapkan bantuan UMKM sesuai kriterianya dalam Undang-Undang Nomor 20 Tahun 2008 tentang Usaha Mikro, Kecil, dan Menengah. Bantuan UMKM sebesar 2,4 Juta rupiah pada tahun 2020 dengan kriteria penerima sebagai berikut:

1. Para pelaku usaha mikro yang sedang tidak menerima kredit modal kerja dari perbankan (unbakable)

2. Pelaku usaha merupakan Warga Negara Indonesia (WNI)

3. Mempunyai Nomor Induk Kependudukan (NIK)

4. Mempunyai usaha mikro yang dibuktikan dengan surat usulan dari pengusul

5. Bukan Aparatur Sipil Negara (ASN), bukan anggota TNI/Polri, dan bukan pegawai BUMN/BUMD. (https://nasional.kontan.co.id/news/umkm-dapat-bantuan-rp-24juta-simak-pengertian-dan-kriterianya?page $=2$, diakses pada tanggal 31 Desember 2020, pukul 10.00 Wib)

Berdasarkan Peraturan Menteri Koperasi dan UKM Nomor 2 Tahun 2021, tentang perubahan atas PERMENKUKM nomor 6 Tahun 2020 Tentang pedoman umum penyaluran bantuan pemerintah bagi pelaku usaha mikro untuk mendukung pemulihan ekonomi nasional dalam rangka menghadapi ancaman yang membahayakan perekonomian nasional serta penyelamatan ekonomi. Penyaluran BPUM melalui Bank BUMN, Bank BUMD, dan PT Pos Indonesia yang ditetapkan oleh KPA. Jumlah bantuan yang diberikan sebesar Rp 1,2 juta untuk pelaku usaha mikro yang memenuhi kriteria.

Selain kebijakan dari aspek ekonomi, pemerintah juga memberikan kebijakan dalam aspek kesehatan sesuai dengan Peraturan Menteri Kesehatan Republik Indonesia Nomor 10 Tahun 2021 Tentang Pelaksanaan Vaksinasi Dalam Rangka Penanggulangan Pandemi Covid-19 (https://persi.or.id/wp-content/uploads/2021/02/pmk10-2021.pdf, diakses pada tanggal 5 April 2021, Pukul 20.07 Wib).

\section{KESIMPULAN}

Virus corona memberikan dampak negatif yang sangat signifikan pada sektor perekonomian beberapa Negara di dunia, termasuk Indonesia. Lumpuhnya ekonomi secara merata mengakibatkan kesengsaraan bagi seluruh lapisan masyarakat terutama masyarakat menengah ke bawah. Sesuai konsep dasar yang terdapat dalam ekonomi makro syariah kehadiran ilmu ekonomi Islam bertujuan membangun mekanisme kekayaan yang adil dan kepedulian di tengah kehidupan masyarakat yang semakin kesulitan ekonomi sehingga menjadikan kesenjangan kehidupan ekonomi dalam masyarakat. 
Perspektif Hukum Ekonomi Syariah: Kebijakan Pemerintah dalam Mengatasi Perekonomian Masa Pandemi Covid 19

Campur tangan pemerintah terhadap situasi dan kondisi pandemic covid 19, sangat dibutuhkan. Melalui kebijakan fiskal dan kebijakan moneter, pemerintah secara tanggap memberikan solusi dan alternatif yang terbaik pada rakyatnya.

\section{DAFTAR PUSTAKA}

Burhanudin, Iksan, Chairul, dan Abdi, Nur, Muhammad, Ancaman Krisis Ekonomi Global Dari Dampak Penyebaran Virus Corona (Covid-19), AkMen, Volume 17 Nomor 1 Maret 2020: 97

Comment, www.thelancet.com, Vol. 395, March 28, 2020, diakses pada tanggal 17 April 2020.

Huda, Nurul, dkk, Ekonomi Makro Islam, Kencana, Jakarta, 2008.

Kemkes RI. 2020. Jaga Diri dan Keluarga Anda dari Virus Corona - Covid-19. [Online] Tersedia pada : www. kemkes.go.id, Diakses 17 April 2020.

Lexy J. Moleong, Metodologi Penelitian Kualitatif, 2017.

Mukharom dan Aravik, Havis, SALAM Volume 7 No. 3 2020, Kebijakan Nabi Muhammad Saw Mengenai Wabah Menular dan Implementasinya Dalam Konteks Menanggulangi Corona Virus Covid 19.

Nurlina T.Muhyiddin, dkk, Metodologi Penelitian Ekonomi dan Sosial, (Jakarta:Salemba Empat, 2017)

Pelu, AS, Pelmi, Ibnu, Gagasan, Tatalan dan Penerapan Ekonomi Syariah Dalam Perspettif Polltik Hukum, Setara Press, Malang, 2008.

Pradja, S, Juhaya, Ekonomi Syariah, Pustaka Setia, Bandung, 2015.

Saiduddin Azwar, Metode Penelitian, Yogyakarta:Pustaka Pelajar Offset, 2001.

Sugiyono, Metode Penelitian Bisnis, Bandung:Alfabeta, 2004.

Sukandarrumidi, Metode Penelitian: Petunjuk Praktis Untuk Peneliti Pemula Cet II, Yogyakarta:Gajah Mada University Press, 2004.

Zulva, Indana, Novita, Tarisa, Covid 19 dan Kecenderungan Psikopatis, Paper, 2020.

Yuniarti, Sri, Vinna, Ekonomi Makro Syariah, Pustaka Setia, Bandung, 2016.

Zarasyi, Fahmy, Hamid, Worldview Islam dan Kapitalisme Barat, Jurnal Tsaqafah, Volume 9 No. 1 April 2013

Rezki, Anissa, dan Yunus, Rohim, Nur, SALAM Vol. 7 No. 3 (2020).

https://www.kompas.com/tren/read/2020/04/01/160000765/5, diakses pada tanggal 17 April 2020, Pukul 09.00 Wib.

https:// persi.or.id/wp-content/uploads/2021/02/pmk10-2021.pdf, diakses pada tanggal 5 April 2021, Pukul 20.07 Wib

https:/ / nasional.kontan.co.id/news/ umkm-dapat-bantuan-rp-24-jutasimak-pengertian-dan-kriterianya? page $=2$, diakses pada tanggal 31 Desember 2020, pukul $10.00 \mathrm{Wib}$. 